\title{
Committee of Electronics and Telecommunications Polish Academy of Sciences Structure - Activities - Perspectives
}

\author{
Józef Modelski and Ryszard Romaniuk
}

\begin{abstract}
Committee of Electronics and Telecommunications of the Polish Academy of Sciences (KEiT PAN) has been acting on behalf of scientific community in Poland since 1960. The article presents structure, statutory tasks, and Committee activities on behalf of the integration and development of electronics and telecommunications sciences and technology in Poland. The Committee of Electronics and Telecommunications of PAS is all the time an active participant of research life in the country. However, this participation is different than it used to be, and all the time is subject to intense changes. The authors present critically the current status of the Committee, but also undertake an effort to newly define the role, activity and potential of KEiT PAN, in completely new conditions of doing research in Poland, Europe and worldwide, than it was at that time, when the PAS Committees were originally defined. The conclusions, upon possible acceptance by the national research and technical communities of electronics and telecommunications, may possibly serve to change and/or optimise the work of the Committee in the near future.
\end{abstract}

Keywords-electronics, telecommunications, Committee of Electronics and Telecommunications, Polish Academy of Sciences, technical sciences in Poland, research conferences, research expertise, information technologies, science policy, science funding

\section{INTRODUCTION}

$\mathbf{T}$ HE Committee of Electronics and Telecommunications of the Polish Academy of Sciences is one of the scientific committees of the PAS, acting within the Division of Technical Sciences (WIV). Academy Committees act, like the rest of the Corporation, during a three year term. The current term has been extended and continues in 2011-2015. Elections to the Committee of the next term will be held in November 2015. The scope of activities of KEiT in the country is associated with the electronics and telecommunications (E\&T) and information technologies, and includes such branches of research as theory and modelling (phenomena, components, devices, systems, signals), nano-electronics and microelectronics (VLSI circuits), optoelectronics (laser technology, optoelectronics imaging, photovoltaics, fibre optics, photonics), signal (analogue and digital signal processing) equipment and systems (theory and applications of electronic systems), materials and technologies (manufacturing of electronic systems in terms of research and industy),

J. Modelski is with Institute of Radioelectronics, Warsaw University of Technology, Warsaw, Poland (e-mail: J.Modelski@ire.pw.edu.pl).

R. Romaniuk is with Institute of Electronic Systems, Warsaw University of Technology, Warsaw, Poland (e-mail: R.Romaniuk@ise.pw.edu.pl). electronic technology, electronic materials technology, hardware and software engineering (hardware and software integration, FPGA/VHDL, DSP, computer engineering), microwave and radar technology (electronics, EM systems, antennas, radars), telecommunications and radio communication (searching, processing, transmission and storage of information), and the Internet/Web engineering.

The Committee works and takes decisions during periodic meetings of the Board, Sections and plenary sessions. Meetings are held alternatively in different universities, R\&D institutes, technology parks and industrial laboratories. The area of the Committee activities includes: publishing of research journals; organization of scientific conferences; initiating new research directions in the field of electronics and telecommunications in Poland; stimulating cooperation between science and economy; preparing expertise for the government, academia and industry; evaluation of candidates for the corresponding members of PAS and for Academy Awards. The Committee has traditionally a strong role in shaping opinion in its operating environment. Together with other committees, members of Technical Sciences Division, the KEiT develops a common opinion in particular fields of science and technology for the needs of the national economy and political sector. The Committee delivers periodic expertise in the area of its competence. KEiT publishes IJET - the International Journal of Electronics and Telecommunications. The Committee co-operates at publishing of the journal of the PAS Division of Technical Sciences - Bulletin of Polish Academy of Sciences - Technical Science.

The members of the Committee are full and corresponding members of the Academy declaring participation, and elected recognized academics and industry leaders. The right to elect members of the Committee have independent academics declaring this branch of science as the main area of their research activities. The Committee has customarily approximately 50 members representing major research centres in electronics and telecommunications in Poland and representing the main topical areas of the Committee activities. If a new field is not sufficiently represented, the Committee may, by voting of the members, call up a relevant recognized expert.

\section{KEIT PAN - ELITE BODY OF PAS}

KEiT has been working for the Polish technical and scientific community since 1960. Many researchers in the field of electronics and telecommunications in Poland are familiar with this activity, either directly or indirectly, by participating in the 
work of the Committee, Sections or its Working Groups, Task Forces, interim Commissions, or taking part in other initiatives, like participation in conferences sponsored by the Committee, writing expertise and ad hoc reviews for the Committee, etc. Over 1000 researchers were co-operating directly with the Committee during this period, and indirectly several times more. Now, each year the Committee and its Sections organize or take patronage over 20 scientific and technical conferences in electronics and telecommunications, national and international, involving together several thousand researchers and scientists. These figures give the impression that the Committee is a mass organization. KEiT is a permanent, elected for 3 year term, elite body of the Academy, organized around the most important issues of science, the activity of academic, technical, administrative, business and industry communities. The Committee is all the time one of the most active participants in the scientific life of the country. However, this participation is different than in the past and continues to rapidly change. Is around this narrow elite really organized science and technology, and high-tech industry of electronics and telecommunications in Poland? Are we able to look critically and constructively at ourselves? The conclusions of these and broader considerations, if they are effectively carried and approved by the national scientific community of electronics and telecommunications, including the Committee, can be used to change or optimize the work of KEiT PAN in the near future. The search for new methods of scientific work and organization, new ways of cooperation and a new place for the Committee in the national research community of electronics and telecommunications is urgent and necessary.

\section{KEIT PAN - CHANGES IN POLISH SCIENCE}

This article is a contribution to the attempt to redefine the role, activities and potential of KEiT in totally different conditions of doing science in Poland and elsewhere, than some time ago when the committees were defined. The authors do not aspire to find and present a general model of optimum performance today and prospects for the future of such bodies as the committees of PAS. It would be a difficult task, probably linked to exposure to discussion and criticism of some of our distinguished colleagues - perhaps a bit more conservative. Or maybe it would be worth anyway, sometime in the near future, to take on such a reliable diagnosis? This article could, perhaps, initiate such a discussion? This discussion is carried out in the framework of the Committee's work, but it seems like it should embrace a wider community. The focus here is more on the common practice of everyday work of such voluntary group of people - members of the Committee, although subject to quite formal elections. A background for KEiT actions will be the PAS Division IV of Technical Sciences, and other committees operating there. The activity of the committees is very different, some are very active, there are plenty of intermediate level, as well as a group of less active. KEiT belongs to the group of large and the most active committees. However, it is a specific activity, centred mainly around the conferences. Some other activities like the impact of opinion leaders in the scientific community and wider sociopolitical communities is not that would agree with the expectations of certain groups of people with bigger and more active ambitions, and above all awaiting a constructive interaction with the public, including economy, industry and policies. When it comes to scientific conferences, here also the matter is complicated. This is a certain tradition of the past, that the Academy and its Committees were organizing numerous conferences. They were designed for this purpose special and quite substantial funds. Today, the Academy supports the conferences (including publications) with much more modest means called the Science Dissemination Activities Fund. As a result, the conferences are organized by specific academic and research institutions and generally financed by the participants. The Academy and Committees take only the esteemed patronage over the conferences. In these new conditions the Committees have not only to survive, but also to maintain their leading role. However, they ceased to be the only and the most important bodies representing specific, generally quite narrow, sometimes somewhat hermetic scientific and technical fields, as it once was in the past.

There is observed a difference of opinion in our community regarding the Committees on what they should do, on one hand by Statute of the Academy and on the second what they can realistically do. Let us try to look more closely at this very question of the future and the changes we undoubtedly face. The look will be limited mainly to the KEiT. Taking such active measures by the committees, particularly from the PAS Division of Technical Sciences in the search for optimal and modern methods of work becomes absolutely necessary in response to the completely changing situation of science. It seems not too strong to say that not understanding the impact of global and local factors on doing science today can lead fairly quickly to the marginalization of organizational structures and even entire communities. Or maybe even better than follow the changes is to participate in them and create them actively. Such a participating committee shall undoubtedly succeed. KEiT PAN aspires to the role of active participant and co-author of dynamic changes of science, probably together with many other, the most active committees of the Academy.

\section{KEIT PAN - PERMANENT BODY OF PAS}

A Scientific Committee is a permanent body of the Academy [1-2]. KEiT PAN [3] is a Scientific Committee of the PAS Division of Technical Sciences [4]. Technical Sciences Division of PAS has a total of 21 Committees: Acoustics, Architecture and Urban Planning, Control and Robotics, Biocybernetics and Biomedical Engineering, Mechanical Engineering, Electronics and Telecommunications, Electrical Engineering, Geodesy, Mining, Computer Science, Chemical and Process Engineering, Civil Engineering, Production Engineering, Environmental Engineering, Mechanics, Metallurgy, Metrology and Scientific Instrumentation, Materials Science, Thermodynamics and Combustion, Transport and Sustainable Mineral Management. KEiT in accordance with the statutes of PAS, is a self-governing nation-wide representation (within the area of sciences and engineering) of the disciplines of electronics and telecommunications. KEiT also represents interdisciplinary research problems related to electronics, photonics, telecommunications, information technologies, as well 
(although there are distinct committees in these disciplines), information technology, energy, electrical engineering, automation and robotics, and materials engineering. Strong drivers of scientific progress in the electronics and telecommunications are space and satellite research as well as the experiments requiring large research infrastructure accelerator and laser technology, new experiments in chemistry, biology, environmental and experimental medicine, and high technology industries. The statutory position of the Scientific Committee of the Academy, including KEiT, is well defined by the type of members and the rules of their elections, the bylaws, structure, and a list of tasks. KEiT is a key advisory and consultative body in the disciplines of E\&T. KEiT works on two levels: social and scientific - political and substantive - specialized expertise. Thus, the task of the Committee is both - to integrate scientific and administrative centres of E\&T and to actively impact the E\&T development in Poland, and solving scientific problems in these disciplines. Such ambitious tasks are feasible if the Committee is (should be) the most representative body of the electronics and telecommunications in the country. The Committee should consist of the most relevant people in the fields.

KEiT consists of: members of PAS active in E\&T, elected members by the research community representing universities, research and scientific institutes, research laboratories, and additionally elected representatives of industry, economic and social organizations. The activity of the Committee is centred around the integration of institutions and researchers across the country in E\&T. The purpose of the Committee is to address substantive scientific issues related to E\&T. The numerous statutory duties of a Scientific Committee are as follows. The Committee should keep active in consulting. Should develop expertise, evaluation and scientific advice to the bodies of the state administration. Should disseminate the results of research. Should be active in the introduction to the practice of economy the results of scientific research. Should initiate research. Should organize conferences and scientific meetings. Should conduct their own publications in the form of journals and publications. In conclusion, the Committee serves as an inspiring body in coordinating the efforts of the Polish scientific and technical communities towards the progress of the country and its role abroad. KEiT supports initiatives aimed at the development of technology and enhancement of the Polish research share on the international arena. KEiT takes patronage over selected national scientific conferences and research projects related to E\&T.

\section{KEIT PAN - STRUCTURE AND ACTIVITIES}

KEiT structure now includes the Board, Permanent Sections, Publishing Office, Task Forces and the Secretariat. KEiT has 7 Sections since several terms and now. The Sections represent strictly defined research topics and act as coordinating bodies in their subject areas. The Sections include members of the Committee and also selected Section Experts. Members of the Committee may declare the work in two Sections. In the current term, some members of the Committee declared the work in three Sections.

\section{A. KEiT Board and Office}

Committee Board works between the plenary meetings of KEiT. The Board consists of the Chair, Vice-Chairs, Heads of fixed Sections and the Secretary, and is supported logistically by the Office. The Board takes initiatives for the entire Committee, prepares plenary meetings, interacts with the Publishing Office and Task Forces, performs certain currently running tasks, etc. During the plenary meetings of the Committee, the Board and the Chair would be authorized to represent the whole Committee on important matters concerning critical scientific expertise of a more general nature, for the government. Specialized expertise is performed by ad hoc teams of experts from KEiT Sections. During the plenary meetings, the Sections present statutory reports from current operations. Most of the Sections are very active, but there is also observed some unevenness in their businesses. Secretariat of the Committee performs the duties including scientific, substantive, administrative and organizational. The Secretariat carries out logistical activities associated with the Committee's technical and professional preparation of presidential and plenary meetings, supporting current operations of the Chairman and the Board of the Committee, supporting Committee reporting - statistics, financial, minutes of meetings, annual reports and other periodic reports, maintaining a website of the Committee, collecting of archival materials, providing information on the activities of the Committee, assisting the organizers of the conference under the auspices of the Committee and Section, piloting science outreach funding, cooperation with the Chairs and the secretariats of the Sections, support of Task Forces, cooperation with the secretariat of the Division of Technical Sciences of PAS, etc. It seems that the Secretariat could even more broadly support the activities of the Committee, which would increase the efficiency and scope of the impact on the national scientific community. This would require probably some form of permanent employment in the Secretariat, which is unlikely. Thus, the Secretariat of the Committee is customarily assisted by the institution which employs the Chair and/or Secretary of the Committee. Currently apparently needed extension activities of the Secretariat would be increasingly required to extend the presence of the Committee on the Internet.

\section{B. KEiT Meetings}

The Committee meetings are definitely an excellent forum for exchanging ideas. Meetings are but fleeting. Protocols are short and concise. Exchange of ideas are accompanied only sometimes by more massive consequences in the form of particular actions. Exchange of ideas is static on the site, but we do not discredit its quite strong function of integrating the community. The Committee should develop efficient mechanisms for transferring the conducted interesting, multithreaded, and very valuable scientific discussion on effective community actions.

\section{KEiT Members Activities}

The activity of individual Committee Members varies widely. The majority of the Members are active or very active. Active members are effectively building the overall activity of the Committee. Some members only rarely attend the meetings of 
the Committee. Some participants of the meetings do not take voice. Has the Committee some impact on the passive Members? Another problem in the operation of the Committee is that some members present their scientific and socio scientific activities as the Committee's activities, despite the fact that the Committee does not have a lot in common. We operate in the Committee together, in a common manner for the benefit of our scientific community and the country.

\section{Section of Electromagnetic Compatibility}

The EMC Section is working under the guidance of prof. Tadeusz Więckowski and it consists of more than 50 people. Subject of the work of the Section are electromagnetic fields as a place of exploitation of electrical, electronic, photonic, and other equipment, interacting with the environment. Electromagnetic compatibility concerns the issue of disturbances and immunity disorders, which test the ability of devices to work properly in a given environment and not emitting disturbances affecting their work and other devices. The Section patrons national and international conferences in the field of EMC. It takes actions related to the development of the EMC research topics in the country. It operates in the area of EMC technical standardization in national and international scale. Standardization is a fundamental requirement of EMC product development of electronic industry. Section patrons the leading EMC meeting of national experts that takes place during the cycle of the National Symposium on Electromagnetic Compatibility in Electrical Engineering and Electronics.

\section{E. Section of Microelectronics}

Section of Microelectronics is working under the guidance of prof. Andrzej Napieralski and it consists of more than 50 people. The subject of the work of the Section is the field of electronics concerning the design and manufacture of semiconductor integrated circuits of very high level of integration. There are expected such features of the designed and studied systems like small size, low power consumption, high speed, low price, high reliability, etc. The most important international event organized in the country under the auspices of the Section is a known world-wide conference MIXDES. Section is working on the development in Poland of a concept of model solutions for fabless microelectronics utilities, with the usage of technology abroad. Such solutions are necessary for economic reasons. Such solution may effectively use the national research capacity in a very attractive research field of microelectronics. Section maintains working contacts with eminent scholars of Polish origin who have made significant scientific achievements in the world in the field of microelectronics.

\section{F. Section of Microwaves and Radiolocation}

The Microwave Section is working under the guidance of prof. Wojciech Gwarek and it consists of approximately 50 people. The subject of the work of the Section is to develop microwave technology, antenna and radio communications. Section patrons to several national conferences in the field of radio communication, radio, television, radar technique - also including cooperation with the Section of Telecommunications. One of such important national events with the broad participation of international visitors in the microwave and radar is International Radar Week which consists of several interconnected conference. Section also is a patron of Digital Signal Processing Conference organized for young researchers.

\section{G. Section of Optoelectronics}

Section of Optoelectronics is working under the guidance of prof. Tomasz Wolinski and it consists of approximately 50 people. The subject of the work of the Section is photonics, fibre optics, optical telecommunications, optoelectronics and imaging, semiconductor components, photonics lighting, sensors and photonic equipment. The specificity of action of the Section of Optoelectronics is close cooperation with the Photonics Society of Poland - publishing Photonics Letters of Poland, and the Polish Committee of Optoelectronics Association of Polish Electrical Engineers, and the Optics Section of the Polish Physical Society. The cooperation of related organizations provide interesting experience with new methods of interaction for development in photonics, technical physics and optical engineering sciences in Poland.

\section{H. Section of Signals, Circuits and Electronic Systems}

The Signals, Circuits and Systems Section is working under the guidance of prof. Marek Domanski and it consists of more than 60 people. The work subject of the Section are signal processing techniques in electronics and information on the physical, software and hardware levels, as well as the design of functional systems for these purposes. Section maintains extensive website, where they collected information not only about the activities of the Section and its meetings, but also data on books and other publications, doctoral work, achievements in the field of research, and conferences. The full list of Members of the Section contains a collection of additional information, including a description of the subject of research conducted by the individuals. Current information on the section activities is published in its online newsletter. In the Bulletin of the Section one may find source materials in a form of scientific presentation files to download, in particular on advanced signal processing methods.

\section{Section of Electron Technology and Technology of Electronic Materials}

The Technology Section is working under the guidance of prof. Marek Tłaczała and it consists of approx. 100 people. The subject of the work of the Section is the technology, source materials for electronics and photonics, through discrete functional elements and methods for their implementation, to complex systems. A particular area of concern is the work program of the Section concerning the scientific development in the country at the level of design and technology of microwave transistor intended for the use in radar technology. In this respect, the cooperation is carried out with the Section of Microwave Technology. The Section patrons to several technology conferences as ELTE Electronic Technology and the National Electronics Conference KKE.

\section{J. Section of Telecommunications}

The Telecom Section is working under the guidance of prof. Józef Wozniak, and it consists of more than 60 people. The subject of the work of Section are telecommunications and related fields such as data communications, databases, global networks, the Internet and the issue of virtualization. Section is 
active in many fields - the science, where it patrons the most important conferences in the national telecommunications, the expert, where it cooperates with the state administration of telecommunications. Section initiates and patrons cooperation with the telecommunications industry. President of the Section has presided recently the jury of the Golden Cyborg Prize, launched by Sprint and awarded annually by the National Telecommunications and Data Communications Symposium KSTiT. The most important event in the area, under the copatronage of the Polish Academy of Sciences, which is the National Conference on Radiocommunications, Broadcasting and Television - KKRRiT combines science, social organizations, operators and state administration. Telecommunications Section supports one of the oldest national magazines in the field, created in 1928 - The Telecommunications Review.

The permanent topical Sections of the Committee, covering particular sub-field of the E\&T described above have strong and substantive justification in their communities. Perhaps one would consider to create an alternative solution, as it is in some of other Committees. The Sections are not subject but task oriented. Such sections are involved in high level of E\&T teaching for masters and doctoral degrees, training of professional E\&T personnel, cooperation between science and the economy, science policy in broader aspect of sociological and political environment, science funding in the E\&T area, designation of the 'road map' covering the thematic priorities and development initiatives, etc.

\section{K. International Journal of Electronics and Telecommunications}

IJET PAN is a publication of more than 60 years of tradition. Recently, the editors-in-chief of the journal were prof. Wiesław Wolinski and prof. Tadeusz Łuba. The journal is published on the Internet, run by the editors, using a popular open digital publisher - Open Journal System - OJS [13]. IJET is indexed in Scopus - Elsevier, OCLC / WorldCat, OAI-PMH, DOAJ, Google Scholar, INSPEC, Index Copernicus, CSA Technology Research, CSA / ProQuest, The Summon / ProQuest, Compendex, High Tech Database Research, BazTech, Ce -On, Pol-On, Knowledge Base of the Warsaw University of Technology, and several other aggregation bibliographic databases, and applies for indexing by the Web of Knowledge - Thomson Reuters [14-15]. IJET publishes approximately 60 peer-reviewed scientific papers per year. KEiT has recently appointed for members of the Editorial Board in the current term several dozen of young professors representing the most active research community of E\&T from around the country. Currently, the index SCOPUS SCImago Journal Rank - SJR (equivalent IF -JCR ISI) for IJET is 0.24.

\section{Monograph - State-of-the-art analysis and development directions of electronics and telecommunications}

A key monograph Analysis of the Status and Trends of Electronics and Telecommunications in 2010 [8] was published by the Committee, in the previous term, edited by Józef Modelski. Subsequent chapters of the monograph were written by the Sections. Parts of the monographs were published internationally in English [9-11]. The monograph was prepared in response to the needs of the national government and the scientific community. Publishing of the monograph was possible thanks to the financial support of the Foundation for the Development of Radiocommunications and Multimedia Technologies, cooperating with the Institute of Radioelectronics, Warsaw University of Technology. The monograph was received with a great interest by the science administration officials, as well as the scientific community of E\&T. Such a good reception of the E\&T monograph encourages the editors to publish the next completely updated issue during the next term of the Committee.

\section{KEiT PAN - Task Forces}

The following Task Forces were active during the current term of the KEiT: TF on the Committee's Structure and Activities, and TF on Cooperation of Economy and Science. TF on Economy and Science, chaired by prof. Antoni Rogalski considered the following issues: possible splitting of KEiT into two separate committees on Electronics and Telecommunications, Committee structure divided to permanent or transient sections, modifications of elections of Committee members, scope and work methods of the Committee in the current situation of the Polish science. Here there are some of the conclusions of the Commission's action, presented by prof. A. Rogalski at one of the recent plenary meetings of the Committee.

\section{N. KEiT Task Force on Committee structure}

As a result of the discussions, the TF recommended not to split the Committee to separate two ones. There are no justified important causes to do so. The committee is working today in relatively difficult conditions, marked by the intense evolution of the organization of new science funding agencies and the methods of distributing the money in the area of science. In such a situation, an established committee should be more consistent, to represent the wider community, and thus be able to have a greater impact, and to seek forms of adequate action which may have a significant, not only declarative impact on the development of electronics and telecommunications in Poland. This effect of real impact, however, can be seen only in the case of the public formulation by the Committee, documented and balanced, yet positive and firm opinions on scientific issues and related socio - economic ones in Poland.

The current structure of the Committee with a number of fixed Sections raises many discussions, both inside and outside of the Committee in the bodies of the Academy. It is suggested that a reduction in the number of permanent Sections, along with the change of the form of their activities may revive the Committee. As an alternative to permanent Sections, it is proposed to appoint interim Task Forces, depending on the current problems, to develop positions and expertise on certain issues. The discussion in this area will continue and the problem of fixed Sections and the form of Sections membership will have to be addressed in the new term.

Elections to the PAS Committees, including KEiT, are common and democratic among the professors of E\&T discipline. In the case of KEiT, representing a very broad and rapidly developing field of science, the number of voters in the country is more than 600. These people, independent researchers, have declared disciplines and specialties of E\&T as leading in their field of research. Subject to elections are independent academics who are not members of the Academy. From among 600 voters over 30 people are elected, and later 
additionally there are elected 10 members who are representatives of industrial research units and the economy. Return of votes is nevertheless relatively high, and for the KEiT is approximately 50\%. Voices from the country are greatly dispersed. It is perhaps a sign of social capital dispersion in the community? A question is if in this situation there are elected the most relevant people to the Committee, the best representatives of science? An alternative to the current system of democratic elections may be to impose a priori clear election preferences. It seems that the current system reconciles some extremes of the election mechanisms, allowing one to respond to the development of the current research situation, and in some way supports logistically the Committee's work. Representatives of the non-university institutions usually logistically support the active work of the Committee, for example by co-organizing the external meetings. Democratic elections ensure that the representation of areas, communities and regions in the Committee is balanced. The problem of the election of members of KEiT is not disclosed so drastically, due to the representation of a very broad discipline of science and technology, and therefore embracing considerable personal representation in the country. The issue of the election of members to the Committees of WIV PAN representing a very narrow field has a completely different character.

An ongoing discussion in the Committee is on the scope and methods of work in the current situation of the Polish science. From this discussion, the suggestion arose that the Committee should hold public positions on current and relevant issues for Polish science in the area of substantive competence of the members of the Committee. In some cases, the Committee speaks indirectly through the PAS Division of Technical Sciences. The Division collects the opinions of the Committees on key issues of science in the country. The Committees have been recently polled in terms of evaluating journals, scientific databases and bibliometrics. New methods of assessment of learning also change quite profoundly same research environment and affect its layers of substance, sociology, economics, scholars career, evaluation of individuals and institutions, and others [12]. The issue of taking by the Committee public positions on scientific and science-society matters is related to many formal questions of Committee reputation, especially in today's period of fairly aggressive journalism also on science and society matters. The Committee has not used excessively till now such opportunities of open public utterances. The important issue is here a closer cooperation with the relevant state authorities in the area of science and economy, as well as the increased presence of the Committee on the Internet.

\section{O. KEiT Task Force on Cooperation of Industry with Science}

TF on Industry and Science worked under the guidance of $\mathrm{dr}$ I. Żmidziński. Multi-person Team, composed of representatives of the economy and the university, presented in the form of seminars during the successive plenary session of the Committee the data on the situation in this area in the country at the background of the European situation. Prof. Bogusław Smólski and prof. Andrzej Kowalski have presented a number of critical comments on the current situation and constructive conclusions showing directions of necessary actions. Still continued discussion in the Committee focuses on issues such as the development of domestic high-tech industry, E\&T prospects of such industry in highly competitive conditions, highly specialized E\&T personnel training for the economy, the free migration of European youth in the areas of science and advanced technology, the potential patronage of the Committee over national priority research programs. Some of the conclusions have been developed in the form of written submissions. Proposals for the telecommunications sector have been transferred to the Ministry of Economy. It seems that this is a very interesting trend of the Committee's work, which should be developed. Opinions under development should be agreed with interested partners. Members of the Committee, coordinating the preparation of such reviews could participate in the continuation of the discussion at the national administration level. The Committee opinions on economy and science are often presented by the members of the Board in national forums. This happened also recently at the 2015 National Economic Forum.

\section{KEIT-PAN - REPORTING AND EVALUATION}

The Committee bylaws requires that it prepares term and annual reports on its work. Annual reports on the activities of the Committee is prepared by the Secretariat on the basis of materials from the operation of the Board of the Committee and the Sections. The recipient of the reports is PAS Division of Technical Sciences. The reports of the Committees gathered in the Division are consolidated and forwarded to the Office of the PAS in order to further consolidate them at the overall level of the Academy. Committee Reports contain chapters on research activities, dissemination, learning activities, publications, developed expertise and opinions, the discussions on matters of science, scientific and economic cooperation, the activities of the Sections, and the important achievements of individual members of the Committee.

Periodic evaluation of the operations of the Committees is done by the central authorities of the Academy on average once every two - three years, or for one or two terms. All Committees, including the WIV PAN were evaluated in the current term. There was conducted an interesting and quite versatile research on the Committee activities. A relevant questionnaire was prepared on the basis of proposals for expected activities of the Committees. Some Committees have prepared the questionnaire perfectly, or almost perfectly. The rating largely depended on the activity of the Committee, but also significantly on how the survey was filled. Quantitative assessment was carried out in a number of aspects, assigning indicators and next number of weighting points. The aspects were: organizational, publishing, expert consultative and influential, online presence and activity. The qualitative assessment categories are taken into account: the information content and attractive web presence, consultative, initiating activities, integrative ones, disciplines achievements in the broader social environment and the scientific community, and promotion of the achievements of young scientists. Committee ranking took into consideration the following indicators: the number of members of the PAU and the AMU and young scientists under 40 years of age, organizing workshops for graduate students, publishing of the scientific journal and its indexation, the issue of extensive studies, expert reports commissioned from outside and on own initiative, published 
technical and scientific opinions and reviews, comments to legislation relating to science, expressing positions on important matters of public debate, published science assessment states, and the popularity of the website. Evaluation of the WIV Committees revealed a significant spread of the ratings reflecting the very different levels of activity. Among 21 Committees of WIV, the KEiT took $7^{\text {th }}$ position with more than $70 \%$ of the points. The following areas require some improvements in the KEiT: expert activities, opinion-forming and opinion-sharing activities, promotion of young scientists, active presence on the Internet, promotion of the KEiT IJET scientific publication to the A list of the Ministry of Science and Higher Education, dissemination and outreach of science, etc. The term "outreach" refers to all science communication and education activities that bring scientific research to audiences outside the research community. It is also known as "popularisation”. Outreach activities are clearly underestimated by the E\&T research communities in Poland.

\section{KEIT PAN - PRESENCE AND ACTIVITY IN INTERNET}

A necessary direction of development of the activities of the Committee is virtualization. KEiT presence on the Internet is now the primary form of information exchange - scientific and administrative, internal and external. KEiT, like other Committees, has an official home page in the Academy Knowledge web portal [keit.pan.pl]. In addition, it has a bilingual homepage related to the work of the Secretariat [keit.ise.pw.edu.pl]. Online public site is used for the purposes of aggregation, information and archives, publishing information about the Committee, people, actions, connecting links of the Section and the activities of the Board of the Committee, the collection of current and archival materials, sharing of expertise. The Intranet is now used only for the purposes of the Secretariat. It is necessary to develop extensively the Internet and Intranet communication platform for both Internet KEiT - public information and Intranet expertise and discussion. KEiT is indexed in Polish Wikipedia [5], Polish Science database [6], a database of OCLC / WorldCat [7], operated by the US Library of Congress. All Sections of the Committee have their own separate Internet home pages [16-22]. Some of these sites are active and contain actual materials from the activity, but some are less active.

Online presence of the Committee should be significantly enhanced with a source materials database and a social layer. This layer is not appreciated at all in the national science and especially in technical sciences. It is much better in this regard in the humanities. At first glance, it seems that it is a simple additional task for the Secretariat of the Committee. Just be sure to complete your absence. Nothing could be further from the truth. Social activities on networks require continuous presence - and just maybe we at the moment cannot afford this. The Secretariat of the Committee would require full-time staff as in a good active journal editorial office. There are needed numerous and continuous contacts with Sections and updating the hot science news. It is a very interesting challenge for the future of our Committee, but also for other Committees and probably for the entire Academy. In terms of active social presence of the Committee (and the Academy), it appears that we are catching up for this to be done. A conservatism and elitism of the Academy and its certain bodies restrain the use of the global network capabilities. This approach is now rarely justified. Professional social networks like LinkedIn, or open social networks like Facebook include all the major portals of extensive research institutions in the world. These portals are connected in a sub-network of institutional and personal, scholars and others interested in learning, mainly young people. Dissemination of science does not succeed anywhere as well as on social networks. Participation in online social networking does not relieve one in any case of having your own website. Global social web presence is not a supplement to your own website. It is quite something else. Today, the presence of KEiT PAN in global network is quite marginal, similarly to other Committees of WIV PAS. Created in 2010, the record for KEiT in Wikipedia raises only a moderate interest, as can be seen from the statistics. Besides, the KEiT record is the only one in Wikipedia from WIV Committees. The whole Academy has just a few of the Committees on the Wiki. It is quite symptomatic. Wikipedia and social media, open and professional, are used massively by young people. Open search of the KEiT keyword gives a few links to the Committee Sections, conferences, and more generally to the administration of Sciences, not much more. It is necessary to change slowly this situation, and the Committee will try to do it.

Yet another important aspect of the global web presence of KEiT is virtualization of the scientific and research community performance. KEiT (other committees of WIV PAN) does not sufficiently use the opportunities offered in this area of networking and global presence. Discussions carried out at the presidential and plenary meetings of the Committee is not sufficiently actively continued between the meetings. Meetings are rather static exchange of information than the initiators of living and continuing discussion with the consequences of some forms of further actions. The Committee should work in the near future on a virtual platform for social networking. Committee should definitely create source materials in the global network. Source materials form the hard core of value in the network. These source materials are all the Committee's own scientific studies, positions and opinions, expertise, problem questions, proposed solutions, project proposals, review of new research directions, reviews of socio-scientific movements, etc. The opinions expressed at meetings of the Committee are sometimes quite strong, but very rarely they come out publically. The Committee should have a good grasp on whom to give the opinions outside - whether it's up in the structures of the Academy or directly to the outside, and perhaps spread on the Internet as source materials.

The planned changes in the operation of the E\&T Committee cannot be a set of distinct, more or less related, individual small and dispersed rationalization. Necessary changes at work and perhaps Committee structure result from systemic social and structural changes in the field of science and higher education at the European level. These changes inside the Committee have to result from a good consensus of the community, despite the fact that such a consensus is quite difficult to obtain. Sometimes the solution of choice is the topdown decision. A visible, active, and socially useful Committee visible and useful socially outgoing is an organization embracing the changes, difficulties and 
undertaking challenges. An open Committee is a body acting actively for the benefit of the society. To be such a useful organization is the strong ambition of the Committee of Electronics and Telecommunications of PAS.

A version of this paper in Polish will be published in Electronika [23].

\section{REFERENCES}

[1] Polska Akademia Nauk, Portal Wiedzy [http://www.pan.pl/]

[2] Polska Akademia nauk, Instytucja Naukowa, Komitety [http://www.instytucja.pan.pl/]

[3] Komitet Elektroniki i Telekomunikacji PAN [keit.pan.pl]; Materiały źródłowe z zebrań i dyskusji Komitetu 2010-2015 [keit.ise.pw.edu.pl];

[4] Wydział IV Nauk Technicznych [http://www.instytucja.pan.pl/index.php/wydziay/wydzia-iv]

[5] Komitet Elektroniki i Telekomunikacji PAN w Wikipedii [http://pl.wikipedia.org/wiki/Komitet_Elektroniki_i_Telekomunikacji_P AN]

[6] Komitet Elektroniki i Telekomunikacji w bazie danych Nauka Polska http://nauka-polska.pl/

[7] Komitet Elektroniki i Telekomunikacji w bazie danych OCLC / WorldCat http://www.worldcat.org/identities/lccn-n87904306/

[8] J.Modelski (red.), Analiza stanu i kierunki rozwoju elektroniki i telekomunikacji, OWPW, Komitet Elektroniki i Telekomunikacji PAN, Warszawa 2010, ISBN 978-83-7207-867-4 http://www.wydawnictwopw.pl/index.php?s=karta\&id=1522

[9] J.Modelski, R.Romaniuk, Electronics and Telecommunications in Poland, Issues and Perspectives: Part 1. Society and Education, Proc. SPIE 7745, art.no.774504, doi: 10.1117/12.871182, 2010
[10] J.Modelski, R.Romaniuk, Electronics and Telecommunications in Poland, Issues and Perspectives: Part 2. Science, Research, Development, Higher Education, Proc. SPIE 7745, art.no.774505, doi: 10.1117/12.871183, 2010

[11] J.Modelski, R.Romaniuk, Electronics and Telecommunications in Poland, Issues and Perspectives: Part 3. Innovativeness, Applications, Economy, Development Scenarios, Politics, Proc.SPIE 7745, art.no.774506, doi: 10.1117/12.871196, 2010

[12] R.S.Romaniuk, Czasopisma NT, Indeksy, Cytowania, Bazy danych, Wydawnictwa cyfrowe, Bibliometria, 2014-2015 Cykl artykułów w Elektronice; cz.1: 55 (07), 168-176; DOI:10.15199/ELE-2014-091; cz.2: 55 (08), 91-101; DOI:10.15199/ELE-2014-117; cz.3: 55 (10), 97111; DOI:10.15199/ELE-2014-182; cz.4: 56 (03), 95-100; w druku; cz.5: 56 (03) 95-100; w druku

[13] International Journal of Electronics and Telecommunications [http://ijet.pl]; Redakcja OJS

[14] IJET w Czytelni Polskiej Akademii Nauk [http://ijet.czasopisma.pan.pl/]

[15] IJET w bazie danych OCLC /WorldCat - LCC - Library of Congress Catalog http://www.worldcat.org/

[16] Sekcja Kompatybilności Elektromagnetycznej [http://www.semckeit.pwr.wroc.pl/]

[17] Sekcja Mikroelektroniki [http://www.sm-keit.dmcs.pl/]

[18] Sekcja Mikrofal i Radiolokacji [http://smir-keit.eti.pg.gda.pl/]

[19] Sekcja Optoelektroniki [http://www.if.pw.edu.pl/ opto/so-keit/]

[20] Sekcja Sygnałów, Układów i Systemów Elektronicznych [http://ssuisekeit.multimedia.edu.pl/index.php]

[21] Sekcja Technologii Elektronowej i Technologii Materiałów Elektronicznych [http://156.17.46.1/zpp/sekcjateitme.php]

[22] Sekcja Telekomunikacji [http://st-keit.eti.pg.gda.pl/]

[23] J.W.Modelski, R.S.Romaniuk, Komitet Elektroniki i Telekomunikacji PAN; Struktura-Działanie-Perspektywy, Elektronika, vol.56, no.5, 2015 